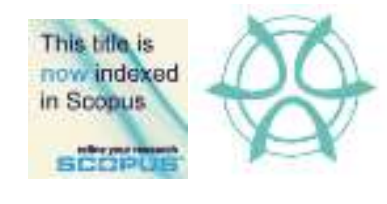

\title{
LANDSCAPE CHARACTERS FOR TOURISM ROUTES: CRITERIA TO ATTRACT SPECIAL INTEREST TOURISTS TO THE KUALA SELANGOR - SABAK BERNAM ROUTE
}

\author{
Khalilah Zakariya ${ }^{1}$, Roziha Che Haron ${ }^{2}$, Izawati Tukiman ${ }^{3}$, \\ Syakir Amir Ab. Rahman ${ }^{4}$ and Nor Zalina Harun ${ }^{5}$ \\ ${ }^{1,2,3,4}$ Kulliyyah of Architecture and Environmental Design \\ INTERNATIONAL ISLAMIC UNIVERSITY MALAYSIA \\ ${ }^{5}$ Institute of Malay World and Civilisation \\ UNIVERSITI KEBANGSAAN MALAYSIA
}

\begin{abstract}
Tourism routes connect the city to the rural areas by linking a variety of activities and attractions. Tourism activities stimulate entrepreneurial opportunities through the development of ancillary products and services. The planning of resources and attractions along the route can be integrated to support the development of a region, conservation and rejuvenation of cultural and natural resources. An attractive route can attract special interest tourists whose travel motivation is to experience the rural environment. This paper examined the landscape characters found along the rural route of Kuala Selangor to Sabak Bernam in Selangor, Malaysia. Based on 250 survey questionnaires among locals and tourists, this study evaluated the importance of nine criteria of the rural tourism route. The findings suggested that the intangible criteria are pertinent to support the tangible criteria. This paper concludes by recommending ways to improve the landscape characters of the route to enrich the tourist experience.
\end{abstract}

Keyword: drive tourism, landscape character, rural tourism, tourism route.

\footnotetext{
${ }^{1}$ Associate Professor at Dept. of Landscape Architecture, KAED, IIUM. Email: khalilah@iium.edu.my
} 
PLANNING MALAYSIA

Journal of the Malaysia Institute of Planners (2020

\section{INTRODUCTION}

Scenery and setting of a destination are essential components in tourism routes. The characteristics of rural landscape along the road can enhance the attractiveness of a tourism destination. Rural tourism depends on the rural landscape characters. Traditional villages and agricultural landscapes need to be conserved and become productive, and tourism activities can become their means of sustainability. This study examined the characteristics of the landscape settings along the west coast route of Selangor, Malaysia, which is from Kuala Selangor to Sabak Bernam. This route is part of the federal road that goes through five areas comprising of towns, rural settlements, agricultural lands, and tourist attractions (Abdul Wahab et al., 2018). The first objective of this paper is to identify the typology of visitors that visit rural areas. The second objective is to outline the significant rural landscape characters for tourism routes as scored by the visitors. The findings from this study outlined the landscape characters that are significant to the planning of tourism route so that it can be sustained alongside the physical development of rural areas.

\section{RURAL LANDSCAPE IN TOURISM}

Rural landscape in this study is defined as a setting that has a prominent physical landscape and is mostly inhabited by the local community that still maintains traditional lifestyle and practices. The process of shaping the rural landscape is undertaken consciously or unconsciously by many different attributes including plants, hills, sea, river, buildings and roads (Harun and Jaffar, 2018; Zakariya et al., 2017). Landscape setting as the image for the rural area is mobilised for a wide variety of purposes that range from ecosystem services to exhaustive experiences that motivate and stimulate tourism activities. The link between rural landscape as an experience and tourism activity is often associated with cultural industries and rural placemaking. Traditional villages, homestays and the rural lifestyles can enrich the experience of visitors. The relationship between landscape and experience demonstrate that rural landscape characters are essential elements that need to be conserved and preserved to attract visitors to visit the rural area.

The National Landscape Department (2012) asserts that the identity of the Malaysian landscape can be recognised and enhanced by conducting landscape character assessments. The landscape features, such as the physiographic character and landform, water body and land cover are the landscape characters at the bigger scale (National Landscape Department, 2012; Brush, Chenoweth and Barman, 2000). The natural landscape can be seen through its types of vegetations, landform and topography (Jaal and Abdullah, 2011). Some of the natural sites become attractions for visitors to do nature-based 
Khalilah Zakariya, Roziha Che Haron, Izawati Tukiman, Syakir Amir Ab. Rahman, Nor Zalina Harun Landscape Characters for Tourism Routes: Criteria to Attract Special Interest Tourists to The Kuala Selangor - Sabak Bernam Route

recreational activities. Likewise, the beautiful scenery is one of the considerations taken by a driver when choosing a route for sightseeing (Hasuike et al., 2013).

The local culture in its geographical setting is an essential aspect of the rural area, as it represents the spirit of the place that shape the senses and nostalgia. The rural atmosphere and local attractions become assets for rural tourism (Fatimah, 2015). Activities such as agriculture activities, playing traditional games, making local crafts, and eating traditional food could enrich the rural tourist experience and cater for different tourist segments. History is also an important component that encapsulates the tangible and intangible values of the past in a place, such as through historical sites, languages, customs and legends (Brown \& Brabyn, 2012; Harun, 2018). This experience is enhanced by the settings of built elements in the rural area, such as traditional architecture, landmarks and rural structures (Mohd Hussain and Byrd, 2011).

\section{TOURISM ROUTE IN RURAL AREAS}

The facilities and infrastructure of the rural routes are essential for a rural tourism destination. Hashim et al. (2013) mentioned that efficient routes would be the chosen route for visitors. The efficient routes should have enough facilities such as petrol station, resting area, public toilet, food stalls and convenient stores. The visitors will usually select a route that seems most interesting to them. The two common options for drivers and motorists are either the highway or the rural route. For locals and visitors using public transportations in the rural areas, concerns should be emphasised on frequency, punctuality, safety and reliability (Ponrahono et al., 2015). Time-dependency is one of the main factors that tourists use to choose the routes. This factor is vital because it determines the duration of travelling and satisfaction values of activities (Hasuike et al., 2013). The shortest route often will be chosen because the visitors could reach the destination in a shorter period, so that they could have more time to enjoy their holiday at the destination (Hashim, Ismail \& Ahmad, 2013). However, if the travel motivation is to experience the attractions along the way, then a longer or rural route may be chosen, so long that the route fulfils the needs of the visitors.

Scenic route between two locations plays a vital role for the visitors to choose. Alivand et al. (2015) mentioned that different routes have different environmental attributes that could attract the tourist. Sightseeing activity and lookout points along the way are some of the important components of tourism route planning as it can influence visitors' choices (Hasuike et al., 2013; Hu \& Ritchie, 1993). A number of researchers found that visitors are attracted to rural environment and attractions due to several factors: the image of rurality (Saxena et al., 2007), the traditional and authenticity (Iaquinto, 2015), sentimental values with personal associations (Dolnicar et al., 2008), integration with natural environment (Lee \& Jan, 2015; Serenari, 2012), integration with local community 
(Mcarthy, 2008; Kastenholz et al., 2018), outdoor and recreational education (Park et al., 2014; Huang et al., 2016). Recently, the rural visitors' motivation is likely to avoid the mass and hectic atmosphere of city pressures, such as noise, pollution, workload and climate ( $\mathrm{Li}$ et al., 2020; Wang \& Yotsumoto, 2019). Other motivational factors that is linked to rural tourists especially in South East Asia is associated with the family origins and visiting family and relatives living in rural areas (Molera \& Albaldejo, 2007), especially during festive seasons. Over time, the rural tourism routes require rejuvenation in terms of planning and design (Pesonen \& Komppula, 2010).

For the rural area, tourism infrastructure includes the physical components that are designed and erected to cater and facilitate the visitors' needs along the side of the road. Physical infrastructure can come in the form of hotels, campsites, restaurants, and sports facilities. The integrated road from one village to another or a direct route from the urban area could attract visitors to visit the rural area (Hasuike et al., 2013). Good infrastructure such as convenient stores, money changer, effective signage and information centre could increase the number of tourists to visit a rural area when they travel. Irshad (2010) highlighted that people travel to the rural areas to experience the various attractions, activities and the village's culture.

Based on the literatures, Table 1 below categorises and summarises nine criteria and their attributes that contribute to the attractiveness and efficiency of rural tourism routes:

Table 1: Rural landscape characters and infrastructure for tourism route

\begin{tabular}{|c|c|c|c|c|}
\hline $\begin{array}{l}\text { Criteria 1: } \\
\text { Rural } \\
\text { Culture }\end{array}$ & $\begin{array}{l}\text { Criteria 2: } \\
\text { Recreational } \\
\text { Activities }\end{array}$ & $\begin{array}{l}\text { Criteria 3: } \\
\text { Traditional Built } \\
\text { Environment }\end{array}$ & $\begin{array}{l}\text { Criteria 4: } \\
\text { Agriculture }\end{array}$ & $\begin{array}{l}\text { Criteria 5: Nature } \\
\text { and Landscape } \\
\text { Features }\end{array}$ \\
\hline $\begin{array}{l}\text { Traditional } \\
\text { villages, } \\
\text { homestay, } \\
\text { rural lifestyle, } \\
\text { traditional } \\
\text { wear, local } \\
\text { food and } \\
\text { products }\end{array}$ & $\begin{array}{l}\text { Traditional } \\
\text { games, } \\
\text { agrotourism, } \\
\text { extreme sports, } \\
\text { festival and } \\
\text { events, user- } \\
\text { based activities }\end{array}$ & $\begin{array}{l}\text { Traditional } \\
\text { houses, rural } \\
\text { structures (foot } \\
\text { bridge, wakaf, } \\
\text { etc.), local } \\
\text { landmarks, local } \\
\text { materials }\end{array}$ & $\begin{array}{l}\text { Crops, } \\
\text { plantations and } \\
\text { farms, fishery, } \\
\text { cottage } \\
\text { industry and } \\
\text { livestock }\end{array}$ & $\begin{array}{l}\text { Natural landscape } \\
\text { (hills, mangrove, } \\
\text { river), village } \\
\text { landscape, nature- } \\
\text { based recreation }\end{array}$ \\
\hline $\begin{array}{l}\text { Criteria 6: } \\
\text { History and } \\
\text { Heritage }\end{array}$ & $\begin{array}{l}\text { Criteria 7: } \\
\text { Sensory and } \\
\text { Experience } \\
\end{array}$ & \multicolumn{2}{|c|}{$\begin{array}{l}\text { Criteria 8: Infrastructure and } \\
\text { Facilities }\end{array}$} & $\begin{array}{l}\text { Criteria 9: } \\
\text { Accessibility }\end{array}$ \\
\hline $\begin{array}{l}\text { Language, } \\
\text { historical sites, } \\
\text { traditional } \\
\text { customs, } \\
\text { legends /myths } \\
\text { /folklore }\end{array}$ & $\begin{array}{l}\text { Rural scenery, } \\
\text { rural sounds, } \\
\text { rural smells, } \\
\text { nostalgia }\end{array}$ & $\begin{array}{l}\text { Petrol station, } \\
\text { directional } \\
\text { signage, public } \\
\text { toilets, religious } \\
\text { facilities, rest } \\
\text { area, } \\
\text { accommodation }\end{array}$ & $\begin{array}{l}\text { Lookout points, } \\
\text { interpretive } \\
\text { signage, visitor } \\
\text { centre, ATM, } \\
\text { convenient } \\
\text { stores }\end{array}$ & $\begin{array}{l}\text { Good road system, } \\
\text { distance between } \\
\text { destinations, public } \\
\text { transportation, } \\
\text { parking }\end{array}$ \\
\hline
\end{tabular}


Khalilah Zakariya, Roziha Che Haron, Izawati Tukiman, Syakir Amir Ab. Rahman, Nor Zalina Harun Landscape Characters for Tourism Routes: Criteria to Attract Special Interest Tourists to The Kuala Selangor - Sabak Bernam Route

\section{METHODOLOGY}

The method employed for this study is through surveying the locals and the visitors. A total of 250 respondents comprising 125 locals and 125 visitors (local visitors and foreign tourists) responded to the questionnaires. The responses were collected based on random samples distributed at five main towns: Kuala Selangor, Tanjung Karang, Sekinchan, Sungai Besar and Sabak Bernam. The questionnaire is formulated based on criteria found to contribute to the rural landscape character for tourism route planning, as shown previously in Table 1. Respondents were required to score the level of significance of each criterion and the attributes between the Likert scale score of 1 to 10.1 is least significant and 10 is most significant. The results were analysed using the mean scoring rank of attributes under the rural landscape characters criteria (rural culture, traditional built environment, agriculture, nature and landscape features, history and heritage, recreational activities, and sensory and experience, with a total of 32 attributes) and tourism infrastructure criteria (infrastructure and facilities, and accessibility, with a total of 16 attributes).

\section{RESULTS AND ANALYSIS \\ Respondents background}

$50 \%$ of the respondents are the local people residing in the area of study, and another $50 \%$ are the visitors, which are from Malaysia and international tourists. $26.3 \%$ of the visitors are from various states in Malaysia, such as Penang, Perak and Sabah. $1.8 \%$ of the visitors are the international tourists from Germany, Italy, USA and Beijing. The majority of the survey respondents are aged between 21$25(37 \%)$ and $16-20(29 \%)$. There is also a relatively balanced distribution between female $(58 \%)$ and male $(42 \%)$ respondents. A large percentage of them came with their families $(81 \%)$ and individually $(11.2 \%)$. The majority of the respondents visit this area during festivals or events $(89.5 \%)$ and occasionally $(2.9 \%)$.

\section{Significant rural landscape characters}

All 32 attributes of rural landscape characters measured in this study received mean scores of 6.0 and above. The highest mean score is 7.65 (Agriculture: Crops) and the lowest mean score is 6.14 (Recreational Activities: Traditional games). On the scale of 1 to 10 , where 10 is most significant, the scores rated by locals and tourists on the attributes of rural landscape characters show the significance of all attributes to represent the rural landscape characters. When the attributes and their mean scores are ranked, the results reveal that the top ten attributes belong to six criteria, which are agriculture, history and heritage, rural culture, nature and landscape features, recreational activities and traditional built environment (refer Table 2). 
Table 2: Significant attributes for rural culture

\begin{tabular}{llcc}
\hline Criteria & Attributes & Mean & Rank \\
\hline Agriculture & Crops & 7.65 & 1 \\
\hline History \& Heritage & Language & 7.42 & 2 \\
\hline Agriculture & Fishery & 7.38 & 3 \\
\hline Rural Culture & Fishermen village & 7.38 & 3 \\
\hline Rural Culture & Local food & 7.33 & 5 \\
\hline Nature \& Landscape Features & Nature-based recreation & 7.31 & 6 \\
\hline Agriculture & Cottage industry & 7.29 & 7 \\
\hline History \& Heritage & Traditional customs & 7.22 & 8 \\
\hline Recreational Activities & Agricultural activities & 7.22 & 8 \\
\hline Traditional Built Environment & Local landmarks & 7.22 & 8 \\
\hline
\end{tabular}

\section{Agriculture}

Agricultural lands are usually the most visible landscape character along the rural route due to their large plots. The most significant attribute for the rural landscape characters in this study is crops (7.65). Other significant agricultural attributes are fishery (7.38) and cottage industry (7.29). Agriculture and fishery activities are determined by the physiographic characters and natural resources of the area. In the Kuala Selangor - Sabak Bernam route, the paddy fields are the most prominent agricultural feature of the area (refer Fig. 1).

\section{History and heritage}

History and heritage connect strongly to the local people, their roots and locations. Language (7.42) is the second most significant attribute of the rural landscape. While language is intangible, local dialects can denote the geographical location of an area and become part of the rural ambience. Another significant attribute is traditional customs (7.22). Traditional customs are commonly promoted as part of rural tourism as it allows visitors to feel like a local and have the opportunity to interact with the locals (refer Fig. 2).
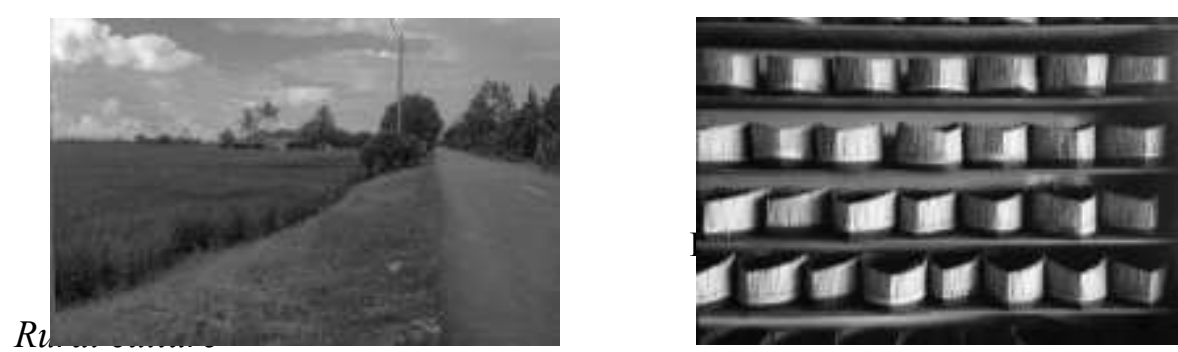
Khalilah Zakariya, Roziha Che Haron, Izawati Tukiman, Syakir Amir Ab. Rahman, Nor Zalina Harun Landscape Characters for Tourism Routes: Criteria to Attract Special Interest Tourists to The Kuala Selangor - Sabak Bernam Route

Rural culture is shaped by the natural and cultural resources of the place. The results show that respondents regarded the fisherman village (7.38) and local food (7.33) to be significant attributes of rural culture. Fishermen village is unique to certain places that are located by the river or the sea. Local food is also influenced by the resources available in the area. In Kuala Selangor, mentarang is a type of shell-fish that is special to the area (refer Fig. 3).

\section{Nature and landscape features}

Nature and landscape features are composed of village landscape, nature-based recreations and the natural landscape such as hills, mangrove and others. However, it is surprising that nature-based recreation (7.31) was found to be more significant than the natural landscape setting (6.97). Since these two attributes are interrelated, the results show that visitors prefer to experience nature through recreational activities rather than just observing nature (refer Fig. 4).

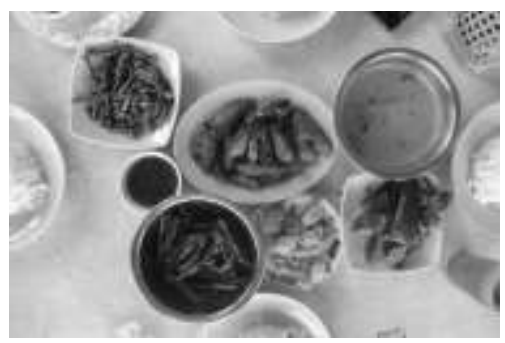

Figure 3: Grilled Mentarang

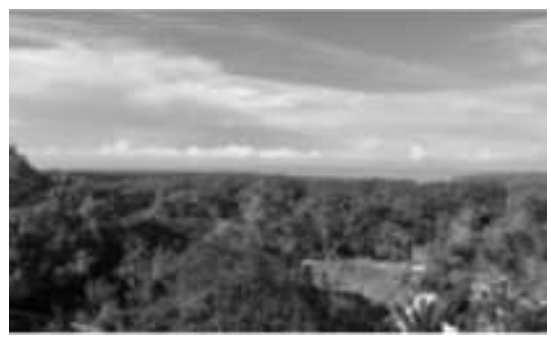

Figure 4: Visitors can go to the peak of Bukit Malawati to enjoy this view

\section{Recreational activities}

Recreational activities include agricultural activities that visitors can participate, traditional games, extreme sports, festivals, events and activities for different user groups. Agricultural activities (7.22) is significant to the rural landscape character since agriculture has been acknowledged to be the most significant criteria.

\section{Traditional built environment}

The traditional built environment consists of local landmarks, local materials, traditional houses, and rural structures. The most significant attribute in the traditional built environment is local landmarks such as mosques and temples (7.22). Their architectural design and location make them stand out from the other built environment features. 


\section{Significant tourism infrastructure}

16 attributes of tourism infrastructure measured in this study received mean scores of 6.0 and above. The highest mean score is 7.56 (Infrastructure \& Facilities: Religious facilities) and the lowest mean score is 6.03 (Accessibility: Public transportation). The scores rated by locals and tourists on the attributes of tourism infrastructure show the significance of all attributes to facilitate tourism activities in the rural areas. When the attributes and their mean scores are ranked, the results reveal that the top ten attributes belong mostly to infrastructure and facilities (refer Table 3).

Table 3: Significant attributes for tourism infrastructure

\begin{tabular}{llcc}
\hline Criteria & Attributes & Mean & Rank \\
\hline Infrastructure and facilities & Religious facilities & 7.56 & 1 \\
\hline Infrastructure and facilities & Directional signage & 7.49 & 2 \\
\hline Infrastructure and facilities & ATM / money changer & 7.44 & 3 \\
\hline Infrastructure and facilities & Petrol station & 7.39 & 4 \\
\hline Infrastructure and facilities & Public toilets & 7.32 & 5 \\
\hline Accessibility & Good road system & 7.08 & 6 \\
\hline Infrastructure and facilities & Interpretive signage & 7.01 & 7 \\
\hline Infrastructure and facilities & Accommodation & 7.01 & 7 \\
\hline Infrastructure and facilities & Lookout points & 6.92 & 9 \\
\hline Infrastructure and facilities & Convenient stores & 6.82 & 10 \\
\hline
\end{tabular}

\section{Infrastructure and facilities}

Infrastructure and facilities along the tourism route are important to support the tourist experience. The respondents regarded the facilities listed in Table 3 to be significant attributes in the rural area during their travels. Most of these integrated facilities can actually be found at the rest areas and some are provided at the petrol stations. The provision of quality infrastructure and facilities can create a positive travel experience for visitors.

\section{Accessibility}

Interstate and regional traveling require good road systems since most of the visitors travel through the rural areas using their own mode of transportation. Good accessibility also includes safety for a smooth journey. Routes that are well connected with attractions and facilities as discussed in the previous findings can contribute to the attractiveness of the journey along the rural areas. 
Khalilah Zakariya, Roziha Che Haron, Izawati Tukiman, Syakir Amir Ab. Rahman, Nor Zalina Harun Landscape Characters for Tourism Routes: Criteria to Attract Special Interest Tourists to The Kuala Selangor - Sabak Bernam Route

\section{DISCUSSION \& RECOMMENDATION}

Nine criteria of rural landscape characters for tourism route and their attributes have been examined based on their significance. The most visible criteria along the route are agriculture, nature and landscape features, and traditional built environment. These physical characters create the setting of the rural landscape and they are easily identifiable through sight. Major crops of the area form the rural landscape character, and rural tourism and agrotourism can be alternative means to how the agricultural plots can be sustained. For the Kuala Selangor Sabak Bernam route, the paddy fields in Sekinchan and Sungai Besar have become one of the main icons in the area. Nature-based recreation should also be promoted as part of rural activities. In the study area, watching the fireflies at night is one of the nature-based activities that visitors can do along the river and mangrove. Nature seems to be more appreciated when they can be experienced. On the other hand, local landmarks such as mosques, temples and other religious institutions should be conserved and sustained as part of the rural landscape, especially when they portray the local architecture.

History and heritage, rural culture and recreational activities are criteria that need to be experienced by visitors. Their significance show that the intangible criteria are as important as the tangible criteria for the visitor to experience. Since tourism is an industry that offers experience as a product to its visitors, these intangible criteria shape the primary aspect of the rural landscape character. The opportunities for visitors to conduct activities along a rural route will differentiate a regular rural route from a rural tourism route. Language and traditional customs attributes that can only be experienced once the visitor engages in the activities at the site, rather than just driving by. Local food and site-specific traditional villages such as the fishermen village can give the visitors a unique experience. The agricultural activities can set the rural areas apart from urban or island tourism attraction. The significance of these attributes suggests that rural tourism routes need to be planned with activities for it to be worthwhile to be visited.

\section{CONCLUSION}

This study concludes by proposing the way forward to sustain rural landscape characters for tourism routes. Natural and cultural resources shape the landscape characters, and therefore, they must not be left out in the future planning of rural areas. A collaboration among landscape architects, planners, local authorities and key players in the tourism industry is essential to ensure that planning is wholistically done by taking into account the local resources into future developments. Programmes and activities to educate the locals and tourists about the uniqueness of the place can also make people more appreciative of the local culture, become potential businesses, and enhance the tourist experience. A 
positive experience can become word-of-mouth promotion and encourage potential repeat visits. As found in this study, tourism infrastructure is integral, and they need to be well-maintained. The provision of quality infrastructure can enhance the overall tourist experience. The future development of the rural areas needs to recognise these criteria as crucial assets for it to be beneficial to both the locals and the visitors.

\section{ACKNOWLEDGEMENTS}

This publication was funded by the Research Initiative Grant Scheme (Publication) by International Islamic University Malaysia (P-RIGS18-0160016). The authors would like to thank Nur Amirah Abdul Wahab for her assistance in this publication.

\section{REFERENCES}

Abdul Wahab, N. A., Zakariya, K., Ibrahim, P. H., \& Ibrahim, I. (2018). Mapping the landscape characters along a rural route for tourism. Planning Malaysia: Journal of the Malaysian Institute of Planners, 16(1), 131-140.

Alivand, M., Hochmair, H., \& Srinivasan, S. (2015). Analysing how travellers choose scenic routes using route choice models. Computers, Environment and Urban Systems, 50, 41-52.

Brown, G., \& Brabyn, L. (2012). An analysis of the relationships between multiple values and physical landscapes at a regional scale using public participation GIS and landscape character classification. Landscape and Urban Planning, 107(3), 317331.

Brush, R., Chenoweth, R., and Barman, T. (2000). Group differences in the enjoyability of driving through rural landscapes. Landscape and Urban Planning. Vol. 47.

Dolnicar, S., Crouch, G. I., \& Long, P. (2008). Environment-friendly tourists: What do we really know about them? Journal of Sustainable Tourism, 16(2), 197-210.

Fatimah, T. (2015). The Impacts of Rural Tourism Initiatives on Cultural Landscape Sustainability in Borobudur Area. Procedia Environmental Sciences, 28 (SustaiN 2014), 567-577.

Harun, N.Z. and Jaffar, N. (2018). Enhancement for rural livability: Changes and impacts on the traditional Malay settlement. Environment-Behaviour Proceedings Journal. $3(9), 127-134$.

Harun, S. N. (2018). Promoting rural tourism in Perak Tengah District through the expanding of heritage interpretation and presentation. Planning Malaysia: Journal of the Malaysian Institute of Planners. 16(3), 182-196.

Hashim, Z., Ismail, W. R., \& Ahmad, N. (2013). Determination of optimal self-drive tourism route using the orienteering problem method. AIP Conference Proceedings, 1522 (April 2013), 1420-1430.

Hasuike, T., Katagiri, H., Tsubaki, H., \& Tsuda, H. (2013). Interactive multi-objective route planning for sightseeing on Time-Expanded Networks under various conditions. Procedia Computer Science, 22, 221-230. 
Khalilah Zakariya, Roziha Che Haron, Izawati Tukiman, Syakir Amir Ab. Rahman, Nor Zalina Harun Landscape Characters for Tourism Routes: Criteria to Attract Special Interest Tourists to The Kuala Selangor - Sabak Bernam Route

Huang, W. J., Beeco, J. A., Hallo, J. C., \& Norman, W. C. (2016). Bundling attractions for rural tourism development. Journal of Sustainable Tourism, 24(10), 13871402 .

Hu, Y. \& Ritchie, J. R. B. (1993). Measuring Destination Attractiveness: A Contextual Approach. Journal of Travel Research, 32, 25-34.

Iaquinto, B. L. (2015). "I recycle, I turn out the lights": Understanding the everyday sustainability practices of backpackers. Journal of Sustainable Tourism, 23(4), 577-599.

Irshad, H. (2010). Rural Tourism - An Overview. Government of Alberta: Agriculture and Rural Development.

Jaal, Z., \& Abdullah, J. (2012). User's preferences of highway landscapes in Malaysia: A review and analysis of the literature. Procedia Social and Behavioral Sciences, 36, $265-272$.

Kastenholz, E., Carneiro, M. J., \& Eusébio, C. (2018). Diverse socializing patterns in rural tourist experiences: A segmentation analysis. Current Issues in Tourism, 21(4), 401-421.

Lee, T. H., \& Jan, F. H. (2015). The influence of recreation experience and environmental attitude on the environmentally responsible behavior of community-based tourists in Taiwan. Journal of Sustainable Tourism, 23(7), 1063-1094.

Li, J.H., Bai, Y. \& Alatalo, J.M. (2020). Impacts of rural tourism-driven land use change on ecosystem services provision in Erhai Lake Basin China. Ecosystem Services. $42,1-10$.

McCarthy, J. (2008). Rural geography: Globalizing the countryside. Progress in Human Geography, 32(1), 129-137

Mohd Hussain, N.H. \& Byrd, H. (2011). Towards a compatible landscape in Malaysia: An idea, challenge and imperatives. Procedia Social and Behavioural Sciences, Vol. 34, 275-283.

Molera, L., \& Albaladejo, P. (2007). Profiling segments of tourists in rural areas of SouthEastern Spain. Tourism Management, 28(3), 757-767.

National Landscape Department (2012). Manual Penilaian Karakter Landskap Malaysia. Kuala Lumpur, Kementerian Perumahan dan KerajaanTempatan.

Park, D. B., Lee, H. J., \& Yoon, Y.S. (2014). Understanding the benefit sought by rural tourists and accommodation preferences: A South Korea case. International Journal of Tourism Research, 16, 291-302.

Pesonen, J., \& Komppula, R. (2010). Rural wellbeing Tourism: Motivations and Expectations. Journal of Hospitality and Management. 17, 150-157.

Ponrahono, Z., Bachok, S., Mohamed Osman, M., Ibrahim, M., Abdullah, M. F., \& Abdulllah, A. (2015). Assessing the urban and rural stage bus services disparities in Peninsula Malaysia. Planning Malaysia: Journal of the Malaysian Institute of Planners. Vol. 13, 65-84.

Saxena, G., Clark, G., Oliver, T., \& Ilbery, B. (2007). Conceptualizing integrated rural tourism. Tourism Geographies, 9(4), 347-370.

Serenari, C., Leung, Y. F., Attarian, A., \& Franck, C. (2012). Understanding environmentally significant behavior among whitewater rafting and trekking 
guides in the Garhwal Himalaya, India. Journal of Sustainable Tourism, 20(5), $757-772$

Wang, L.G., \& Yotsumoto, Y. (2019). Conflict in tourism development in rural China. Tourism Management. 70, 188-200.

Zakariya, K., Ibrahim, P.H., and Abdul Wahab, N.A. (2017). Landscape character assessment for Malaysia's rural landscape: A conceptual framework. In: Persidangan Kebangsaan Masyarakat, Ruang \& Alam Sekitar (MATRA) 2017, $23^{\text {rd }}-24^{\text {th }}$ February 2017, Penang.

Received: $15^{\text {th }}$ May 2020. Accepted: $1^{\text {st }}$ Sept 2020 